\title{
Bacteria are more sensitive to nitrogen fertilizer application in tea plantation soil while fungi are more correlated to tea yield and quality
}

\section{Sheng Tang}

Zhejiang University

Jingjie Zhou

Zhejiang University

Wankun Pan

Zhejiang University

Rui Tang

Anhui Agricultural University

Qingxu Ma ( $\nabla$ afpade@bangor.ac.uk)

Bangor University https://orcid.org/0000-0003-2050-7725

\section{Meng Xu}

Zhejiang University

\section{Tong Qi}

Zhejiang University

\section{Zhengbo Ma}

Chinese Academy of Agricultural Sciences

Haoran Fu

Zhejiang University

Lianghuan Wu

Zhejiang University

\section{Research Article}

Keywords: Bacteria, Fungi, Tea yield, Tea quality, N fertiliser application

Posted Date: November 5th, 2021

DOI: https://doi.org/10.21203/rs.3.rs-939956/v1

License: (1) (1) This work is licensed under a Creative Commons Attribution 4.0 International License.

Read Full License 


\section{Abstract}

\section{Aims}

Soil in tea plantations is characterised by severe acidification and high aluminium and fluorine content. Applying excessive nitrogen $(\mathrm{N})$ is a common strategy in tea plantations. Fungal and bacterial responses to $\mathrm{N}$ fertiliser addition in tea plantations, especially their relationship with tea growth, quality, and soil microbiome composition, remain unclear.

\section{Methods}

We performed a field experiment using different $\mathrm{N}$ fertiliser application rates for 5 years (2016-2020) in a tea-producing region of China.

\section{Results}

Application of excessive $\mathrm{N}\left(600 \mathrm{~kg} \mathrm{ha}^{-1} \mathrm{y}^{-1}\right)$ reduced tea yield and quality. High $\mathrm{N}$ application rates (360 and $\left.600 \mathrm{~kg} \mathrm{ha}^{-1} \mathrm{y}^{-1}\right)$ significantly decreased bacterial and fungal diversity and altered the compositions of bacterial and fungal communities $(P<0.05)$. Fungi were more tolerant than bacteria to soil environmental changes induced by $\mathrm{N}$ fertiliser application. Succession of bacterial and fungal communities was mostly driven by $\mathrm{pH}$. Partial least square path modelling suggested that $\mathrm{N}$ addition directly influenced the diversity and communities of bacteria and fungi, and indirectly influenced bacterial community and fungal diversity by mediating soil nutrients and $\mathrm{pH}$. The assembly of fungal communities was more regulated by dispersal limitation and deterministic processes than that of bacterial communities. High microbial diversity was not a requirement for tea growth.

\section{Conclusions}

Fungi had a greater impact on tea yield and quality than bacteria; therefore, more attention should be given to fungi, which play a stable role in nutrient cycling and organic matter decomposition in tea plantation, eventually favouring tea growth.

\section{Highlights}

- Application of excessive $\mathrm{N}$ reduced tea yield and quality.

- High $\mathrm{N}$ application rates significantly decreased bacterial and fungal diversity.

- Stochastic processes contributed more to bacterial community assembly than to fungal community assembly in tea plantation soil

- Fungi have a greater impact on tea yield and quality than bacteria. 


\section{Introduction}

Tea (Camellia sinensis) is mainly distributed in tropical and subtropical areas with acidic soils (Yan et al., 2018). The unique flavour and health benefits of tea have increased its demand, leading to an expansion of tea-farming area (FAO, 2019; Musial et al., 2020). As a leaf-harvest crop, tea requires more nitrogen (N) to meet the demand for leaf growth and metabolite synthesis than cereal crops, such as maize, rice, and wheat (Tang et al., 2020). Chemical fertiliser application is a practical method for improving tea yield and quality (Wang et al., 2020). In practice, excessive fertiliser (especially $\mathrm{N}$ fertiliser) is applied to tea plantations ( $\mathrm{Ni}$ et al., 2019; Tang et al., 2021b). In China, the average $\mathrm{N}$ fertiliser application rate is $491 \mathrm{~kg}$ ha $^{-1}$; excessive $\mathrm{N}$ fertiliser application results in soil acidification, eutrophication, and nitrous oxide emissions in 32.2\% of tea plantations (Guo et al., 2010; Huang et al., 2017; Wang et al., 2018b; Ni et al., 2019). Moreover, excessive $\mathrm{N}$ fertiliser application inhibits theanine and polyphenol synthesis, which contributes to a bitter taste and inferior quality of tea (Ruan et al., 2007; Ruan et al., 2010).

Soil bacteria and fungi play vital roles in maintaining soil productivity, including nutrient cycling, organic matter decomposition, and soil structure composition (Bahram et al., 2018; Kuypers et al., 2018; Naylor et al., 2020). Studies have focussed on bacterial and fungal responses to $\mathrm{N}$ addition in terrestrial ecosystems (Geisseler and Scow, 2014; Li et al., 2020b). In arable soils, bacterial and fungal communities are affected when the physicochemical and structural properties of soil are altered by farming practices, such as irrigation, residue return, and fertiliser application (Geisseler and Scow, 2014; de Vries et al., 2018; Chen et al., 2021). Bacteria and fungi have different niches and community assemblies in soil and respond differently to environmental changes. (Schneider et al., 2012; Reay et al., 2019; Jiao et al., 2021a; Zheng et al., 2021). In soil, bacterial networks are more fragile than fungal networks under drought conditions (de Vries et al., 2018). The fungi to bacteria ratio decreases with an increase in the $\mathrm{N}$ fertiliser application rate (Zhang et al., 2018). Bacterial beta diversity and the stochasticity ratio first increase and then decrease with an increasing $\mathrm{N}$ fertiliser rate, whereas fungal beta diversity is not influenced and the stochasticity ratio decreases with an increasing $N$ fertiliser rate in temperate steppes (Liu et al., 2021). However, a study on temperate grasslands suggested that the fungal community is more sensitive to $\mathrm{N}$ addition than the bacterial community (Widdig et al., 2020).

Tea plantation soil is highly acidic; the characteristics high aluminium and fluorine content shape the unique soil microbial community of tea plantations (Shu et al., 2003; Hu et al., 2017; Ji et al., 2018a). Therefore, in the context of global soil acidification, tea plantation soil is optimal for studying the impact of acidification and soil microbial characteristics under highly acidic conditions (Guo et al., 2010). In a subtropical tea plantation, soil fungal community structure was shown to be significantly altered and fungal diversity decreased under higher $\mathrm{N}$ input due to a shift in soil and pruning characteristics (Yang et al., 2019). Organic substitution for synthetic $N$ fertiliser can also shift the characteristics of bacterial and fungal communities in tea plantations (Ji et al., 2018b; Ji et al., 2020). However, these studies focused only on soil bacteria and fungi individually. The effects of $\mathrm{N}$ addition on soil bacteria and fungi in tea plantations, especially their association with tea yield and quality, remain unclear. 
Investigating the assembly process of the microbial community can provide new insights into microbial community succession and assist in exploring microbial function (Stegen et al., 2013; Zhou and Ning, 2017). The soil microbe assembly process is significantly correlated with soil properties, climate change, and land-use history (Zhang et al., 2016; Li et al., 2018; Shi et al., 2018). However, to our knowledge, the assembly process of the microbiome distributed in tea plantation soil, especially the effect of $\mathrm{N}$ fertiliser application on microbial assembly, has not been investigated.

In this study, a field experiment with different $\mathrm{N}$ fertiliser application rates was commenced in 2016 in a tea-producing area of China. Tea and soil samples were collected in 2020 to evaluate the following: (1) bacterial and fungal community succession under $\mathrm{N}$ fertiliser application conditions, (2) factors driving microbial community, (3) consistency of assembly processes of bacteria and fungi under $\mathrm{N}$ fertiliser application, and (4) relationship between bacteria and fungi with tea yield and quality.

\section{Material And Methods}

\subsection{Field experiment design}

The field experiment was conducted in Shaoxing City, Zhejiang Province, China ( $\left.29^{\circ} 5616^{\prime \prime} \mathrm{N}, 120^{\circ} 4145^{\prime \prime} \mathrm{E}\right)$ during 2016-2020. The experimental site is located in a subtropical monsoon climate region with an annual average temperature of $16.4^{\circ} \mathrm{C}$ and mean annual precipitation of $1,300 \mathrm{~mm}$. The soil is Haplic Acrisol, according to the Food and Agriculture Organization standards. The initial physicochemical characteristics of soil were $\mathrm{pH} 3.98,2.75 \%$ soil organic carbon (SOC), $0.17 \%$ total nitrogen (TN), 146.04 mg kg-1 alkali-hydrolysable N (AN), $182.67 \mathrm{mg} \mathrm{kg}^{-1}$ available phosphorus (AP), and $75.78 \mathrm{mg} \mathrm{kg}^{-1}$ $\mathrm{NH}_{4} \mathrm{OAc}-\mathrm{K}$ (AK). The experimental treatments were set as follows: $\mathrm{NO}$ ( $\mathrm{N}$ deficiency treatment: $0 \mathrm{~kg} \mathrm{~N} \mathrm{ha}^{-1}$ $\mathrm{y}^{-1}$ ), N1 (low $\mathrm{N}$ application rate: $120 \mathrm{~kg} \mathrm{~N} \mathrm{ha}^{-1} \mathrm{y}^{-1}$ ), N2 (optimal $\mathrm{N}$ application rate: $360 \mathrm{~kg} \mathrm{~N} \mathrm{ha-1} \mathrm{y}^{-1}$ ), and N3 (excessive $\mathrm{N}$ application rate: $600 \mathrm{~kg} \mathrm{~N} \mathrm{ha}^{-1} \mathrm{y}^{-1}$ ) (Ruan et al., 2020). $\mathrm{P}_{2} \mathrm{O}_{5}$ and $\mathrm{K}_{2} \mathrm{O}$ application rates were 80 and $100 \mathrm{~kg} \mathrm{ha}^{-1} \mathrm{y}^{-1}$, respectively, for all treatments. Urea, single superphosphate, and potassium sulphate were selected as $\mathrm{N}, \mathrm{P}$, and $\mathrm{K}$ fertilisers, respectively. $\mathrm{N}$ fertiliser was applied as a base fertiliser at the rate of $30 \%$ for 2 months after autumn tea harvest, $30 \%$ for 1 month before spring tea harvest, $20 \%$ for 1 month before summer tea harvest, and $20 \%$ for 1 month before autumn tea harvest. $P$ and $\mathrm{K}$ fertilisers were applied as base fertilisers for 2 months after the autumn tea harvest. All fertilisers were applied at a soil depth of $15 \mathrm{~cm}$ between tea rows and covered with soil. The four treatments were conducted in a $2 \times 18 \mathrm{~m}^{2}$ experimental plot with three replicates for each treatment based on a randomised block design.

\subsection{Tea sampling and analysis}

Tea leaves with one bud and two young expanding leaves were harvested in April, July, and September 2020 as spring, summer, and autumn teas, respectively. Tea yield was determined using a $30 \times 30 \mathrm{~cm}$ stainless-steel frame, and adjusted to $75 \%$ of water content. The tea samples were processed for enzyme inactivation immediately after harvest. Subsequently, the samples were oven-dried at $70^{\circ} \mathrm{C}$ for $48 \mathrm{~h}$ before 
being sieved through a $250-\mu \mathrm{m}$ screen. Finally, dry samples were extracted with boiling water to evaluate tea quality. Samples were incubated with ninhydrin to calorimetrically quantify the total amount of free amino acids (AAs) in tea leaves at $570 \mathrm{~nm}$ using a spectrophotometer (UV-1780, Shimadzu, Japan). Samples were incubated with the Folin-Ciocalteu reagent for quantifying tea polyphenols at $765 \mathrm{~nm}$ using a spectrophotometer (UV-1780, Shimadzu, Japan) (Tang et al., 2021b).

\subsection{Soil sampling and analysis of physicochemical characteristics}

Soil samples from topsoil $(0-25 \mathrm{~cm})$ and subsoil $(25-50 \mathrm{~cm})$ were collected after the spring tea harvest in April 2020. The soil samples were divided into two parts: the first was air-dried to determine its physicochemical properties and the second was stored at $-80^{\circ} \mathrm{C}$ for the analysis of soil bacteria and fungi. The $\mathrm{pH}$ of soil extracted with deionised water (soil:deionised water $=1: 5$ ) was measured using the Delta $320 \mathrm{pH}$ meter (Mettler-Toledo Instruments Co., Shanghai, China). $\mathrm{K}_{2} \mathrm{Cr}_{2} \mathrm{O}_{7}$ oxidation-reduction titration, Kjeldahl digestion, and alkaline diffusion were used to determine the SOC, TN, and AN, respectively. Soil samples were extracted with $2 \mathrm{M} \mathrm{KCl}$ (soil: $\mathrm{KCl}$ solution = 1:10) and soil $\mathrm{NH}_{4}{ }^{+}-\mathrm{N}$ and $\mathrm{NO}_{3}{ }^{-}-\mathrm{N}$ concentrations were analysed using a continuous flow analyser (SAN++, Skalar, The Netherlands). Soil AP was extracted using the $\mathrm{HCl}-\mathrm{NH}_{4} \mathrm{~F}$ solution (soil: $\mathrm{HCl}-\mathrm{NH}_{4} \mathrm{~F}$ solution $=1: 10$ ) and determined calorimetrically at $700 \mathrm{~nm}$ using the molybdenum blue method. Soil samples were extracted with $\mathrm{CH}_{3} \mathrm{COONH}_{4}$ solution (soil: $\mathrm{CH}_{3} \mathrm{COONH}_{4}=1: 10$ ) to evaluate $\mathrm{AK}$ using a flame photometer (INESA 6400A, INESA, Shanghai, China).

\subsection{Soil DNA extraction and sequencing of bacteria and fungi}

Soil DNA was extracted from 0.5-g soil samples using the FastDNA Spin Kit (MP Biomedicals, Solon, OH, USA) following the manufacturer's protocol. The NanoDrop 2000 spectrophotometer (Thermo Scientific, Waltham, MA, USA) was used to analyse the concentration and quality of the extracted DNA. The V4-V5 regions of 16S rRNA genes were amplified using primers 515F (5'-GTGCCAGCMGCCGCGGTAA-3') and 907R (5'-CCGTCAATTCMTTTRAGTTT-3') (Tang et al., 2021a). Primers ITS1-F (5'-

CTTGGTCATTTAGAGGAAGTAA-3') and ITS2-2043R (5'-GCTGCGTTCTTCATCGATGC-3') were used to amplify the ITS1 region. Sequencing of polymerase chain reaction products was performed using the Illumina Novaseq platform. Bacterial and fungal sequence data were processed using an in-house pipeline (http://mem.rcees.ac.cn:8080). Same operational taxonomic units were clustered at $97 \%$ similarity. Annotation of taxonomic data for representative sequences of bacteria and fungi were processed using the SILVA (https://www.arb-silva.de/) and UNITE (version 8.0, https://unite.ut.ee) databases, respectively.

\subsection{Statistical analysis}

All data analyses were performed using R (version 4.0.5). The Shapiro-Wilk test was used to assess normality prior to testing significance. Differences in soil and tea characteristics between treatments were 
analysed using one-way analysis of variance (ANOVA) and the least significant difference test $(P<0.05)$. Interactions between harvest seasons and treatments were investigated using two-way ANOVA. Random forest analysis was performed using the 'randomForest' package in R. Differences in bacterial and fungal community structures were analysed using non-metric multidimensional scaling (NMDS) based on the Bray-Curtis dissimilarities. Canonical redundancy analysis (RDA) and Mantel's test were implemented using the 'vegan' package in $\mathrm{R}$ to investigate the contribution of soil properties to bacterial and fungal communities. Partial least squares path modelling (PLS-PM) was performed using the 'plspm' package in $\mathrm{R}$ to investigate the relationships between $\mathrm{N}$ fertiliser application rate, soil characteristics, and bacterial and fungal community diversity. The contributions of neutral processes to the assembly of bacterial and fungal communities in soil were evaluated using the neutral community model (NCM) proposed by Sloan et al. (2006). In this model, $\mathrm{R}^{2}$ represents the overall goodness-of-fit of the neutral community model. The $\mathrm{Nm}$, which indicates the migration rate between microbial communities, was calculated by multiplying the metacommunity size and immigration. The parameter $\mathrm{m}$ indicates the migration rate (Burns et al., 2016; Chen et al., 2019).

\section{Results}

\subsection{Effect of $\mathbf{N}$ fertiliser application on the physicochemical characteristics of soil}

$\mathrm{N}$ addition altered the physicochemical characteristics of topsoil and subsoil (Table S1). Overall, soil nutrients distributed in the subsoil were present at lower concentrations than in the topsoil. Under N2 and $\mathrm{N} 3$ conditions, a significant decrease in soil pH and SOC content was observed in the topsoil compared with that under $\mathrm{N} 0$ conditions $(P<0.05)$, whereas there was no significant difference in soil $\mathrm{pH}$ between different $\mathrm{N}$ application rates in the subsoil. SOC content under N3 conditions in the topsoil and subsoil decreased by $31.8 \%$ and $38.4 \%$, respectively, compared with that under NO conditions. Soil TN and AN decreased as the $\mathrm{N}$ fertiliser application rate increased. Under N3 conditions, TN and AN in topsoil decreased by $32.9 \%$ and $19.8 \%$, respectively, compared with under NO conditions. N addition increased soil $\mathrm{NH}_{4}{ }^{+}-\mathrm{N}$ and $\mathrm{NO}_{3}{ }^{-}-\mathrm{N}$ contents and decreased soil AP and AK contents. Nevertheless, 5 years of $\mathrm{N}$ fertiliser application did not significantly alter soil $\mathrm{C} / \mathrm{N}$ in the topsoil or subsoil. Pearson's correlation analysis results indicated a significant negative correlation between soil $\mathrm{NO}_{3}{ }^{-}-\mathrm{N}$ content and soil $\mathrm{pH}$ (Fig. S1). A significantly positive correlation was observed between SOC and soil TN, AN, AP, and AK.

\subsection{Tea yield and quality under different $\mathbf{N}$ fertiliser application rates}

Compared with under NO conditions, tea yields significantly increased in spring, summer, and autumn under N2 and N3 conditions $(P<0.05)($ Fig. 1A). In all harvest seasons, tea yield increased with $\mathrm{N}$ application rate increasing until the $\mathrm{N}$ application rate $>360 \mathrm{~kg} \mathrm{ha}^{-1} \mathrm{y}^{-1}$. Annual yield was defined as the total yield of spring, summer, and autumn tea. Under N1, N2, and N3 conditions annual tea yield 
increased by $16.4 \%, 37.0 \%$, and $33.6 \%$, respectively, compared with under N0 conditions. The results of two-way ANOVA analysis indicated that the $\mathrm{N}$ fertiliser application rate and the harvest season had significant effects on tea yield.

Figure 1. Tea yield and quality under different $\mathrm{N}$ fertiliser rates in spring, summer, and autumn. Standard deviations of three replicates are represented as error bars. Different letters above the bars indicate significant differences $(P<0.05)$ between $\mathrm{N}$ fertiliser treatments in the same harvest season. N0, N1, N2, and $N 3$ refer to $N$ fertiliser application rates of $0,120,360$, and $600 \mathrm{~kg} \mathrm{ha}^{-1} \mathrm{y}^{-1}$ for 5 years.

Under N1, N2, and N3 conditions, AA content significantly increased $(P<0.05)$ by $11.6 \%, 17.2 \%$, and $17.2 \%$, respectively, for spring tea compared with that under $\mathrm{N} 0$ conditions, whereas the $\mathrm{N}$ fertiliser application rate did not have a significant effect on the AA content in summer or autumn tea (Fig. 1B). When the $\mathrm{N}$ fertiliser application rate was $>360 \mathrm{~kg} \mathrm{ha}^{-1}$, the AA content no longer increased with an increase in the $\mathrm{N}$ fertiliser application rate. For all harvest seasons, the highest TP content was observed under NO conditions (Fig. 1C). Conversely, under N2 conditions, the lowest TP content was found in all teas, except for spring tea. Average TP contents of all $\mathrm{N}$ application rates were $14.9 \%, 19.7 \%$, and $27.8 \%$ for spring, summer, and autumn, respectively. $\mathrm{N}$ addition significantly decreased TP/AA in spring tea compared with that under N0 conditions (Fig. 1D). The lowest TP/AA ratio was observed under N2 conditions for summer and autumn tea. Compared with under NO conditions, TP/AA under N2 conditions decreased by $26.3 \%, 25.6 \%$, and $15.6 \%$ in spring, summer, and autumn, respectively. Two-way ANOVA results suggested that the $\mathrm{N}$ fertiliser application rate and harvest season had significant effects on $\mathrm{AA}$, TP, and TP/AA. However, the interactions between $\mathrm{N}$ fertiliser application and harvest season had no significant effect on AA and TP contents or TP/AA.

\subsection{Bacterial and fungal community succession under $\mathbf{N}$ fertiliser application}

The alpha diversities of the bacterial communities decreased with increasing $\mathrm{N}$ application rates (Fig. 2A and 2B). Excessive $\mathrm{N}$ fertiliser application significantly decreased fungal Chao1 index of topsoil $(P<0.05)$ (Fig. 2C). Two-way ANOVA analysis suggested that $\mathrm{N}$ application significantly altered the alpha diversities of bacterial and not fungal communities (Fig. 2F). The soil sampling layer had a significant effect on the Chao1 index of the fungal community. Pearson's correlation analysis results also indicated that the alpha diversities of soil bacteria were more sensitive to soil physicochemical characteristics than soil fungi. Chao 1 and Shannon indices of soil bacteria were positively correlated with soil $\mathrm{pH}, \mathrm{SOC}, \mathrm{TN}$, and AK contents $(P<0.05)$. However, only soil $\mathrm{NH}_{4}{ }^{+}-\mathrm{N}$ and $\mathrm{AN}$ content were negatively correlated with the Chao1 and Shannon indices of the fungal community, respectively.

Figure 2. Chao1 and Shannon indices of $(A, B)$ bacterial and $(C, D)$ fungal communities under different $N$ fertiliser application rates. Standard deviations of three replicates are represented as error bars. Different letters above the bars indicate significant differences $(P<0.05)$ between $\mathrm{N}$ fertiliser treatments under the same soil layer (topsoil: 0-25 cm, subsoil: 25-50 cm). N0, N1, N2, and N3 refer to N fertiliser application 
rates of $0,120,360$, and $600 \mathrm{~kg} \mathrm{ha}^{-1} \mathrm{y}^{-1}$, respectively, for 5 years. (E) Pearson's correlation between soil properties and alpha diversity of bacteria and fungi. Red and blue boxes indicate positive and negative correlations between alpha diversity index and soil properties. (F) Two-way ANOVA analysis results; ${ }^{*} P$ $0.05,{ }^{*} P<0.01$, and $* \star \star P<0.001$. SOC: soil organic carbon; TN: total nitrogen; AN: alkali-hydrolysable N; AP: available phosphate; AK: available potassium.

$\mathrm{N}$ addition altered the relative abundances of the dominant bacterial and fungal phyla present in soil (Fig. 3). The phyla Proteobacteria, Acidobacteria, Chloroflexi, and Actinobacteria accounted for up to $75 \%$ of soil bacteria (Fig. 3A) Basidiomycota, Mortierellomycota, and Ascomycota contributed to up to $35 \%$ of soil fungi (Fig. $3 \mathrm{C}$ ). The relative abundance of Proteobacteria increased with increasing $\mathrm{N}$ application rates. The top 10 phyla of soil bacteria were more sensitive to $\mathrm{N}$ fertiliser application and the sampling layer than those of soil fungi (Fig. 3B and 3D). Results from Pearson's correlation analysis suggested that the dominant bacterial phyla were more sensitive to soil physicochemical properties than dominant fungal phyla (Fig. 3B and 3D). The phyla Acidobacteria, Actinobacteria, Planctomycetes, and Firmicutes were positively and Proteobacteria and WPS-2 were negatively correlated with soil nutrient content. The fungal phyla Cercozoa and Zoopagomycota were negatively and Mortierellomycota and Rozellomycota were positively correlated with soil nutrient content. NMDS results indicated that soil bacterial and fungal community structures were significantly altered after $\mathrm{N}$ addition (Fig. 4A and 4B). Bacterial and fungal community structures distributed in the topsoil and subsoil were significantly different $(P<0.05)$, and were significantly correlated with soil pH $(P<0.05)$ (Fig. 4C and 4D).

\subsection{Driving factors and assembly of soil bacterial and fungal communities}

RDA results revealed that soil $\mathrm{pH}, \mathrm{SOC}, \mathrm{AN}, \mathrm{AK}, \mathrm{NH}_{4}{ }^{+}-\mathrm{N}$, and $\mathrm{NO}_{3}{ }^{-}-\mathrm{N}$ were the main factors driving the bacterial community (Fig. 5A). The soil fungal community was significantly correlated with soil pH, SOC, $\mathrm{C} / \mathrm{N}, \mathrm{AK}, \mathrm{NH}_{4}{ }^{+}-\mathrm{N}$, and $\mathrm{NO}_{3}{ }^{-}-\mathrm{N}$ (Fig. 5B). Mantel's analysis showed that soil pH, SOC, TN, AN, and AK had stronger correlations with the bacterial community than with the fungal community (Fig. 5C).

However, the soil fungal community was more sensitive to soil $\mathrm{NH}_{4}{ }^{+}-\mathrm{N}$ and AP contents. Results from PLS-PM analysis also suggested that bacterial and fungal diversity was negatively correlated with $\mathrm{N}$ fertiliser application $(P<0.05)$, whereas bacterial and fungal communities were positively correlated with the $\mathrm{N}$ fertiliser application rate $(P<0.05)$ (Fig. 6). $\mathrm{N}$ addition influenced the bacterial community by indirectly altering the soil conditions ( $\mathrm{SOC}, \mathrm{TN}$, and $\mathrm{AK}$ ) and $\mathrm{pH}$.

A higher $\mathrm{R}^{2}$ of subsoil suggested that bacteria and fungi distributed in subsoil fitted the NCM better than that in the topsoil, which indicated that the stochastic processes of bacterial and fungal communities increased with the increase in the soil depth (Fig. S2). The migration rates of bacterial and fungal communities in the subsoil were higher than those in the topsoil. Overall, compared with the fungal community, the bacterial community was shaped more by stochastic processes. The migration of the 
fungal community was more restricted than the bacterial community. Cluster analysis classified NO and N1 samples of topsoil and subsoil into one category and N2 and N3 of topsoil into another category, according to soil physicochemical properties (Fig S3). To investigate the impact of $\mathrm{N}$ on bacterial and fungal community assemblies, N0 and N1 samples were clustered into a low N fertiliser application rate group, whereas N2 and N3 samples were clustered into a high N fertiliser application rate group (Figs. S4 and S5). The migration rates of bacterial and fungal communities were restricted after high $\mathrm{N}$ fertiliser application compared to low $\mathrm{N}$ fertiliser application.

\subsection{Random forest analysis of tea yield and quality}

Random forest analysis was applied to predict the driving factors of tea yield and quality (Fig. 7). The results suggested that the variation in tea yield was mainly driven by beta and alpha diversities of bacterial and fungal communities (Fig. 7A). The most correlated factor for tea yield was the beta diversity of the fungal community. Tea quality was most associated with soil AK; the correlation between tea quality and fungal beta diversity was higher than that with bacterial beta diversity (Fig. 7B). Moreover, Pearson's correlation analysis results suggested that microbial alpha diversity was significantly negatively correlated with tea yield, whereas no significant correlation between microbial alpha diversity and tea quality was observed (Fig. 7).

\section{Discussion}

\subsection{Effect of $\mathbf{N}$ input on soil and tea characteristics}

Soil physicochemical properties were markedly altered after N addition (Table S1). N2 and N3 conditions affected soil properties more significantly than N1 conditions (Fig. S3). In addition, the effects of N input on topsoil were more apparent than those on subsoil. The decrease of soil pH after $\mathrm{N}$ input was related to the release of Al ions (Ruan et al., 2006). Interestingly, after excessive N input, SOC and soil TN decreased simultaneously to maintain a stable $\mathrm{C} / \mathrm{N}$ ratio, since $\mathrm{N}$ addition caused a stoichiometric imbalance and decreased the microbial C utilization efficiency, which stimulated SOC decomposition (Li et al., 2021 a; Li et al., 2021b). The soil microbiome regulated stoichiometric stability after nutrient addition (Ma et al., 2021).

Excessive $\mathrm{N}$ addition decreased the yield and quality of tea (Fig. 1). These results suggested that highest tea yield and quality could be achieved under $\mathrm{N} 2$ conditions. In practice, the $\mathrm{N}$ fertiliser application rate under N2 conditions is recommended for green tea production (Ruan et al., 2020). N1 conditions could not meet the $\mathrm{N}$ requirement for tea growth. Overuse of $\mathrm{N}$ fertiliser decreases soil $\mathrm{pH}$ and causes adverse soil conditions (Table S1), which inhibit the synthesis of biochemical components, thereby decreasing tea yield (Ruan et al., 2007; Ma et al., 2013). For instance, arginine and not theanine forms when excessive $\mathrm{N}$ fertiliser is applied, resulting in a bitter taste and decreased quality of tea (Ruan et al., 2007). TP/AA is a comprehensive indicator, negatively correlated with green tea quality (Li et al., 2020a). $\mathrm{N}$ fertiliser application contributed to the synthesis of AA and decreased the TP content, thereby decreasing TP/AA (Fig. 1). Spring tea was of a higher quality than summer or autumn tea (Fig. 1D), owing to the optimal 
spring climate accompanied with suitable temperature and sufficient rain that favour tea growth (Wang et al., 2011); long-term nutrient accumulation from basal fertiliser application to spring tea harvest also contributes to the synthesis of quality ingredients (Sun et al., 2019).

\subsection{Succession of bacterial and fungal community under $\mathrm{N}$ fertiliser application}

Microbial diversity is related to the soil nutrient cycle and contributes to the maintenance of soil function (Zheng et al., 2019; Jiao et al., 2021a). The decrease in bacterial diversity was more apparent than that of fungal diversity with $\mathrm{N}$ fertiliser application so as to benefit fungi. This could be explained by the niche differentiation between bacteria and fungi related to their different responses to soil character changes induced by $\mathrm{N}$ fertiliser application (Fig. 2E), which has also been demonstrated in previous studies (Dai et al., 2018; Wang et al., 2018a; Liu et al., 2021). Generally, the Chao1 index was more sensitive than the Shannon index under $\mathrm{N}$ fertiliser application conditions (Fig. 2). The Chao1 index accounts for species richness and reflects rare species change, whereas the Shannon index suggests both evenness and abundance of species (Shannon, 1948; Chao, 1984). Therefore, the decrease in the fungal Chao1 index indicated that more rare species disappeared, whereas the evenness and abundance of species distributed in the fungal community were not altered under $\mathrm{N}$ fertiliser application conditions.

The distribution of the major phyla of both bacteria and fungi was altered by $\mathrm{N}$ fertiliser application (Fig. 3). Overall, disturbance of the microbiome was more apparent in the topsoil than in the subsoil; topsoil is more susceptible to farmer practice, animal disturbance, and climate change than subsoil (Jiao et al., 2021a). The bacterial phyla Proteobacteria and Actinobacteria and fungal phylum Ascomycota benefitted from $\mathrm{N}$ fertiliser application, whereas the relative abundances of Acidobacteria and Basidiomycota decreased after $\mathrm{N}$ addition (Fig. 3A and 3C). These results are consistent with the oligotroph-copiotroph theory (Fierer et al., 2007; Yao et al., 2017). Proteobacteria, Actinobacteria, and Ascomycota are classified as copiotrophic taxa, whereas Acidobacteria and Basidiomycota are oligotrophic taxa according to the oligotroph-copiotroph theory, which is based on the net carbon mineralisation rate of soil (Fierer et al., 2007). Changes of oligotrophic and copiotrophic taxa under $\mathrm{N}$ fertiliser application conditions contributed to SOC mineralisation, which led to a decrease in the SOC content (Table S1). The shift in the relative abundance of the dominant phyla was attributed to the increase in $\mathrm{N}$ supply, which met the higher $\mathrm{N}$ demand of copiotrophic bacteria than that of oligotrophic bacteria (Fierer et al., 2007). Moreover, under $\mathrm{N}$ fertiliser application conditions, tea production and organic carbon levels increased, which might also have contributed to changes in the dominant phyla (Fierer et al., 2007; Fierer et al., 2012). The microbial community was significantly influenced by $\mathrm{N}$ fertiliser application and soil sampling layer $(P<0.05)$; soil bacteria were more sensitive to the sampling layer (Fig. 4A and 4B). Soil pH was the most important factor regulating both bacterial and fungal communities (Fig. 4C and 4D). Soil acidification induced by $\mathrm{N}$ fertiliser application imposes strong environmental filtering, which leads to microbial community assembly through deterministic processes (Leff et al., 2015; Glassman et al., 2017; Tripathi et al., 2018). Similar to the diversity and dominant phyla responses of bacteria and fungi to changes in soil physicochemical characteristics (Fig. 3B and 3D),the 
results shown in Fig. 5C indicate that bacterial communities were more associated with soil properties than fungal communities. Studies have shown that fungi are more tolerant to adverse environments, including soil acidification (Rousk et al., 2010) and drought (de Vries et al., 2018) than bacteria. Compared with fungi, the $\mathrm{pH}$ range suitable for bacterial growth is narrower (Rousk et al., 2010).

Overall, the NCM results indicated that the fungal community migration rate $(m=0.025)$ was much lower than that of the bacterial community $(m=0.459)$ (Fig. S2). Previous studies also demonstrated that dispersal limitation has a greater impact on fungi than bacteria because of their larger size (Schmidt et al., 2014; Chen et al., 2020; Liu et al., 2021). Moreover, the increase in the stochastic process and migration rate of both bacteria and fungi from topsoil to subsoil may be partly explained by the alleviation of subsoil acidification, which affects microbial community distribution (Tripathi et al., 2018). In this study, we found that the fungal stochastic process increased, whereas richness decreased, with an increasing rate of $\mathrm{N}$ application (Figs. 2 and S5). Jiao et al. (2021b) also reported that fungal richness decreased with increasing stochastic process, and thus influenced ecosystem functions driven by biodiversity (Jiao et al., 2021a). In tea plantation, assembly process of fungi was more susceptible to $\mathrm{N}$ fertiliser application than that of bacteria (Figs. S4 and S5).

\subsection{Relationship between bacteria, fungi, and tea}

The soil microbiome participates in the nutrient cycle and contributes to plant growth (Saleem et al., 2019). In this study, fungal and bacterial communities and diversity were the most relevant indicators of tea yield. Fungi were more associated with tea yield and quality than bacteria (Fig. 7A and 7B). K plays a vital role in the synthesis of caffeine, AAs, and water-extractable dry matter; thus, soil AK is closely related to tea quality (Fig. 7B) (Ruan et al., 2013). Fungi and bacteria play vital roles in pathogen defence and soil organic matter mineralisation, which leads to a release of available nutrients, thus favouring plant growth (Saleem et al., 2019; Jiao et al., 2021a). Microbial diversity contributes to abiotic and biotic stress resistance, multiple functions, nutrient cycling, and plant productivity because of selection effects, complementarity, or redundancy (Saleem et al., 2019). However, we found that microbial alpha diversity is negatively correlated with tea yield (Fig. 7D and 7F). Although $\mathrm{N}$ fertiliser application supplied nutrients that contribute to tea growth, it caused an increase in soil acidification, thereby decreasing microbial alpha diversity. A study also reported that microbial diversity is not always positively correlated with function and productivity (Zhang et al., 2019). Yang et al. (2019) reported that the fungal Chao1 index was negatively correlated with tea pruning biomass. In other words, microbial diversity is not a requirement for the perfect outcome of microbial community because of functional redundancy (Shade, 2017; Louca et al., 2018). In tea plantations, various amounts of pruning litter fall onto the soil surface every year, resulting in the availability of large amounts of nutrients for the microbiome (Yang et al., 2019; Tang et al., 2021a). The possible reason for the close connection between tea and fungi may be that fungi are the initial consumers of plant $\mathrm{C}$ input to the rhizosphere (root exudates) (Ballhausen and de Boer, 2016) and soil surface (pruning litter) (Yang et al., 2019). Fungi tend to decompose recalcitrant SOC, such as lignin and cellulose, and bacteria utilise fungal-derived products (de Boer et al., 2005). This decomposition-niche differentiation between fungi and bacteria contributes to nutrient cycling. Moreover, 
fungi were more tolerant to adverse environments, including $\mathrm{N}$-induced acidification, than bacteria, thus playing a more stable role under $\mathrm{N}$ fertiliser application conditions (Figs. 2, 3, and 5).

\section{Conclusion}

In this study, the response of tea plants, bacteria, and fungi under 5-year $\mathrm{N}$ fertiliser application conditions were systematically investigated. Excessive $\mathrm{N}$ fertiliser application decreased tea yield and quality. Moreover, $\mathrm{N}$ fertiliser application significantly decreased bacterial and fungal diversity and altered bacterial and fungal compositions and communities. $\mathrm{N}$ fertiliser application favoured the growth of copiotrophic taxa (Proteobacteria, Actinobacteria, and Ascomycota) and inhibited oligotrophic taxa (Acidobacteria and Basidiomycota). Bacteria are more sensitive to environmental variations than fungi, and soil $\mathrm{pH}$ was the most important factor driving bacterial and fungal community succession. Stochastic processes contributed more to bacterial community assembly than to fungal community assembly in tea plantation soil. Tea yield and quality were more associated with fungi than bacteria based on random forest analysis. In conclusion, considering the extreme environment of tea plantation soil (i.e., low pH and high $\mathrm{F}$ and $\mathrm{Al}$ contents) and the tolerance of fungi for extreme environments, future studies should investigate the association between fungi and tea growth.

\section{Declarations}

\section{Author contributions}

Sheng Tang: Conceptualisation, Methodology, Formal analysis, Writing - Original Draft. Lianghuan Wu: Conceptualisation, Methodology, Formal analysis. Qingxu Ma: Conceptualisation, Methodology, Formal analysis, Writing - Original Draft. Tong Qi: Conceptualisation, Methodology, Formal analysis, Writing - Original Draft. Zhengbo Ma: Investigation. Rui Tang: Investigation. Wankun Pan: Investigation. Haoran Fu: Investigation. Jingjie Zhou: Investigation. MengXu: Investigation.

Funding: This work was supported by the National Key Research and Development Program of China grant number [2020YFD1100402] and the National Natural Science Foundation of China grant numbers [31801936, 31872180].

Declaration of interests $\square$ The authors declare that they have no known competing financial interests or personal relationships that could have appeared to influence the work reported in this paper.

\section{References}

1. Bahram M, Hildebrand F, Forslund SK, Anderson JL, Soudzilovskaia NA, Bodegom PM, BengtssonPalme J, Anslan S, Coelho LP, Harend H, Huerta-Cepas J, Medema MH, Maltz MR, Mundra S, Olsson PA, Pent M, Põlme S, Sunagawa S, Ryberg M, Tedersoo L, Bork P (2018) Structure and function of the global topsoil microbiome. Nature 560:233-237 
2. Ballhausen MB, de Boer W (2016) The sapro-rhizosphere: Carbon flow from saprotrophic fungi into fungus-feeding bacteria. Soil Biol Biochem 102:14-17

3. Burns AR, Stephens WZ, Stagaman K, Wong S, Rawls JF, Guillemin K, Bohannan BJM (2016) Contribution of neutral processes to the assembly of gut microbial communities in the zebrafish over host development. ISME J 10:655-664

4. Chao A (1984) Nonparametric estimation of the number of classes in a population. Scand J Stat $11: 265-270$

5. Chen J, Wang PF, Wang C, Wang X, Miao LZ, Liu S, Yuan QS, Sun SH (2020) Fungal community demonstrates stronger dispersal limitation and less network connectivity than bacterial community in sediments along a large river. Environ Microbiol 22:832-849

6. Chen QY, Liu ZJ, Zhou JB, Xu XP, Zhu YJ (2021) Long-term straw mulching with nitrogen fertilization increases nutrient and microbial determinants of soil quality in a maize-wheat rotation on China's Loess Plateau. Sci Total Environ 775:12

7. Chen WD, Ren KX, Isabwe A, Chen HH, Liu M, Yang J (2019) Stochastic processes shape microeukaryotic community assembly in a subtropical river across wet and dry seasons. Microbiome $7: 2$

8. Dai ZM, Su WQ, Chen HH, Barberán A, Zhao HC, Yu MJ, Yu L, Brookes PC, Schadt CW, Chang SX, Xu JM (2018) Long-term nitrogen fertilization decreases bacterial diversity and favors the growth of Actinobacteria and Proteobacteria in agro-ecosystems across the globe. Glob Change Biol 24:34523461

9. de Boer W, Folman LB, Summerbell RC, Boddy L (2005) Living in a fungal world: impact of fungi on soil bacterial niche development. FEMS MicroBiol Rev 29:795-811

10. de Vries FT, Griffiths RI, Bailey M, Craig H, Girlanda M, Gweon HS, Hallin S, Kaisermann A, Keith AM, Kretzschmar M, Lemanceau P, Lumini E, Mason KE, Oliver A, Ostle N, Prosser JI, Thion C, Thomson B, Bardgett RD (2018) Soil bacterial networks are less stable under drought than fungal networks. Nat Commun 9:3033

11. FAO (2019) (Food and Agriculture Organization of the United Nations). Production FAOSTAT http://faostat3.fao.org

12. Fierer N, Bradford MA, Jackson RB (2007) Toward an ecological classification of soil bacteria. Ecology 88:1354-1364

13. Fierer N, Lauber CL, Ramirez KS, Zaneveld J, Bradford MA, Knight R (2012) Comparative metagenomic, phylogenetic and physiological analyses of soil microbial communities across nitrogen gradients. ISME J 6:1007-1017

14. Geisseler D, Scow KM (2014) Long-term effects of mineral fertilizers on soil microorganisms - A review. Soil Biol Biochem 75:54-63

15. Glassman SI, Wang IJ, Bruns TD (2017) Environmental filtering by $\mathrm{pH}$ and soil nutrients drives community assembly in fungi at fine spatial scales. Mol Ecol 26:6960-6973 
16. Guo JH, Liu XJ, Zhang Y, Shen JL, Han WX, Zhang WF, Christie P, Goulding KW, Vitousek PM, Zhang FS (2010) Significant acidification in major Chinese croplands. Science 327:1008-1010

17. Hu X-F, Chen F-S, Wine ML, Fang X-M (2017) Increasing acidity of rain in subtropical tea plantation alters aluminum and nutrient distributions at the root-soil interface and in plant tissues. Plant Soil 417:261-274

18. Huang J, Xu CC, Ridoutt BG, Wang XC, Ren PA (2017) Nitrogen and phosphorus losses and eutrophication potential associated with fertilizer application to cropland in China. J Clean Prod 159:171-179

19. Ji L, Ni K, Ma L, Chen Z, Zhao Y, Ruan J, Guo S (2018a) Effect of different fertilizer regimes on the fungal community of acidic tea-garden soil. Acta Ecol Sin 38:8158-8166

20. Ji L, Wu Z, You Z, Yi X, Ni K, Guo S, Ruan J (2018b) Effects of organic substitution for synthetic N fertilizer on soil bacterial diversity and community composition: A 10-year field trial in a tea plantation. Agr Ecosyst Environ 268:124-132

21. Ji LF, Ni K, Wu ZD, Zhang JW, Yi XY, Yang XD, Ling N, You ZM, Guo SW, Ruan JY (2020) Effect of organic substitution rates on soil quality and fungal community composition in a tea plantation with long-term fertilization. Biology Fertility of Soils 56:633-646

22. Jiao S, Peng Z, Qi J, Gao J, Wei G (2021) Linking bacterial-fungal relationships to microbial diversity and soil nutrient cycling. mSystems 6:e01052-e01020

23. Jiao S, Zhang B, Zhang G, Chen W, Wei G (2021b) Stochastic community assembly decreases soil fungal richness in arid ecosystems. Molecular ecology

24. Kuypers MMM, Marchant HK, Kartal B (2018) The microbial nitrogen-cycling network. Nat Rev Microbiol 16:263-276

25. Leff JW, Jones SE, Prober SM, Barberán A, Borer ET, Firn JL, Harpole WS, Hobbie SE, Hofmockel KS, Knops JMH, McCulley RL, La Pierre K, Risch AC, Seabloom EW, Schütz M, Steenbock C, Stevens CJ, Fierer N (2015) Consistent responses of soil microbial communities to elevated nutrient inputs in grasslands across the globe. Proc Natl Acad Sci USA 112:10967-10972

26. Li J, Sang CP, Yang JY, Qu LR, Xia ZW, Sun H, Jiang P, Wang XG, He HB, Wang C (2021a) Stoichiometric imbalance and microbial community regulate microbial elements use efficiencies under nitrogen addition. Soil Biol Biochem 156:108207

27. Li JH, Zhang R, Cheng BH, Ye LF, Li WJ, Shi XM (2021b) Effects of nitrogen and phosphorus additions on decomposition and accumulation of soil organic carbon in alpine meadows on the Tibetan Plateau. Land Degradation Development 32:1467-1477

28. Li X, Jousset A, de Boer W, Carrión VJ, Zhang T, Wang X, Kuramae EE (2019) Legacy of land use history determines reprogramming of plant physiology by soil microbiome. The ISME Journal $13: 738-751$

29. Li X, Li MH, Deng WW, Ahammed GJ, Wei JP, Yan P, Zhang LP, Fu JY, Han WY (2020a) Exogenous melatonin improves tea quality under moderate high temperatures by increasing epigallocatechin-3gallate and theanine biosynthesis in Camellia sinensis L. J Plant Physiol 253:153273 
30. Li YL, Tremblay J, Bainard LD, Cade-Menun B, Hamel C (2020b) Long-term effects of nitrogen and phosphorus fertilization on soil microbial community structure and function under continuous wheat production. Environ Microbiol 22:1066-1088

31. Liu WX, Liu LL, Yang X, Deng MF, Wang Z, Wang PD, Yang S, Li P, Peng ZY, Yang L, Jiang L (2021) Long-term nitrogen input alters plant and soil bacterial, but not fungal beta diversity in a semiarid grassland. Global Change Biology, 1-12

32. Louca S, Polz MF, Mazel F, Albright MBN, Huber JA, O'Connor MI, Ackermann M, Hahn AS, Srivastava DS, Crowe SA, Doebeli M, Parfrey LW (2018) Function and functional redundancy in microbial systems. Nature Ecology Evolution 2:936-943

33. Ma L, Chen J, Shan Y, Jiang M, Zhang G, Wu L, Ruan J, Lv J, Shi Y, Pan L (2013) Status and suggestions of tea garden fertilization on main green tea-producing counties in Zhejiang Province. Journal of Tea Science 33:74-84

34. Ma Q, Kuzyakov Y, Pan W, Tang S, Chadwick DR, Wen Y, Hill PW, Macdonald A, Ge T, Si L, Wu L, Jones DL (2021) Substrate control of sulphur utilisation and microbial stoichiometry in soil: Results of 13C, $15 \mathrm{~N}, 14 \mathrm{C}$, and $35 \mathrm{~S}$ quad labelling. The ISME Journal

35. Musial C, Kuban-Jankowska A, Gorska-Ponikowska M (2020) Beneficial properties of green tea catechins. Int J Mol Sci 21:11

36. Naylor D, Sadler N, Bhattacharjee A, Graham EB, Anderton CR, McClure R, Lipton M, Hofmockel KS, Jansson JK (2020) Soil microbiomes under climate change and implications for carbon cycling. In: Gadgil A, Tomich TP (eds) Annual Review of Environment and Resources, vol 45. Annual Reviews, Palo Alto, pp 29-59

37. Ni K, Liao W, Yi X, Niu S, Ma L, Shi Y, Zhang Q, Liu M, Ruan J (2019) Fertilization status and reduction potential in tea gardens of China. Journal of Plant Nutrition Fertilizers 25:421-432

38. Reay MK, Charteris AF, Jones DL, Evershed RP (2019) N-15-amino sugar stable isotope probing (N$15-\mathrm{SIP})$ to trace the assimilation of fertiliser-N by soil bacterial and fungal communities. Soil Biol Biochem 138:10

39. Rousk J, Baath E, Brookes PC, Lauber CL, Lozupone C, Caporaso JG, Knight R, Fierer N (2010) Soil bacterial and fungal communities across a pH gradient in an arable soil. The ISME Journal 4:13401351

40. Ruan J, Gerendas J, Haerdter R, Sattelmacher B (2007) Effect of root zone pH and form and concentration of nitrogen on accumulation of quality-related components in green teat. J Sci Food Agric 87:1505-1516

41. Ruan J, Haerdter R, Gerendas J (2010) Impact of nitrogen supply on carbon/nitrogen allocation: a case study on amino acids and catechins in green tea [Camellia sinensis (L.) O. Kuntze] plants. Plant Biol 12:724-734

42. Ruan J, Ma L, Shi Y (2013) Potassium management in tea plantations: Its uptake by field plants, status in soils, and efficacy on yields and quality of teas in China. J Plant Nutr Soil Sci 176:450-459 
43. Ruan J, Ma L, Yi X, Shi Y, Ni K, Liu M, Zhang Q (2020) Integrated nutrient management in tea plantation to reduce chemical fertilizer and increase nutrient use efficiency. Journal of Tea Science 40:85-95

44. Ruan JY, Ma LF, Shi YZ (2006) Aluminium in tea plantations: Mobility in soils and plants, and the influence of nitrogen fertilization. Environ Geochem Health 28:519-528

45. Saleem M, Hu J, Jousset A (2019) More than the sum of its parts: Microbiome biodiversity as a driver of plant growth and soil health. In: Futuyma DJ (ed) Annual Review of Ecology, Evolution, and Systematics, vol 50. Annual Reviews, Palo Alto, pp 145-168

46. Schmidt SK, Nemergut DR, Darcy JL, Lynch R (2014) Do bacterial and fungal communities assemble differently during primary succession? Mol Ecol 23:254-258

47. Schneider T, Keiblinger KM, Schmid E, Sterflinger-Gleixner K, Ellersdorfer G, Roschitzki B, Richter A, Eberl L, Zechmeister-Boltenstern S, Riedel K (2012) Who is who in litter decomposition? Metaproteomics reveals major microbial players and their biogeochemical functions. The ISME Journal 6:1749-1762

48. Shade A (2017) Diversity is the question, not the answer. The ISME Journal 11:1-6

49. Shannon CE (1948) A mathematical theory of communication. The Bell System Technical Journal 27:379-423

50. Shi Y, Li YT, Xiang XJ, Sun RB, Yang T, He D, Zhang KP, Ni YY, Zhu YG, Adams JM, Chu HY (2018) Spatial scale affects the relative role of stochasticity versus determinism in soil bacterial communities in wheat fields across the North China Plain. Microbiome 6, 12

51. Shu WS, Zhang ZQ, Lan CY, Wong MH (2003) Fluoride and aluminium concentrations of tea plants and tea products from Sichuan Province, PR China. Chemosphere 52:1475-1482

52. Sloan WT, Lunn M, Woodcock S, Head IM, Nee S, Curtis TP (2006) Quantifying the roles of immigration and chance in shaping prokaryote community structure. Environ Microbiol 8:732-740

53. Stegen JC, Lin XJ, Fredrickson JK, Chen XY, Kennedy DW, Murray CJ, Rockhold ML, Konopka A (2013) Quantifying community assembly processes and identifying features that impose them. The ISME Journal 7:2069-2079

54. Sun LL, Liu Y, Wu LQ, Liao H (2019) Comprehensive analysis revealed the close relationship between $\mathrm{N} / \mathrm{P} / \mathrm{K}$ status and secondary metabolites in tea leaves. ACS Omega 4:176-184

55. Tang S, Liu YL, Zheng N, Li Y, Ma QX, Xiao H, Zhou X, Xu XP, Jiang TM, He P, Wu LH (2020) Temporal variation in nutrient requirements of tea (Camellia sinensis) in China based on QUEFTS analysis. Sci Rep 10:10

56. Tang S, Ma Q, Luo J, Xie Y, Hashmi MLUR, Pan W, Zheng N, Liu M, Wu L (2021a) The inhibition effect of tea polyphenols on soil nitrification is greater than denitrification in tea garden soil. The Science of the Total Environment 778:146328-146328

57. Tang S, Zheng N, Ma Q, Zhou J, Sun T, Zhang X, Wu L (2021b) Applying nutrient expert system for rational fertilisation to tea (Camellia sinensis) reduces environmental risks and increases economic benefits. J Clean Prod 305:127197 
58. Tripathi BM, Stegen JC, Kim M, Dong K, Adams JM, Lee YK (2018) Soil pH mediates the balance between stochastic and deterministic assembly of bacteria. The ISME Journal 12:1072-1083

59. Wang C, Liu DW, Bai E (2018a) Decreasing soil microbial diversity is associated with decreasing microbial biomass under nitrogen addition. Soil Biol Biochem 120:126-133

60. Wang JY, Chadwick DR, Cheng Y, Yan XY (2018b) Global analysis of agricultural soil denitrification in response to fertilizer nitrogen. Sci Total Environ 616:908-917

61. Wang LY, Wei K, Jiang YW, Cheng H, Zhou J, He W, Zhang CC (2011) Seasonal climate effects on flavanols and purine alkaloids of tea (Camellia sinensis L.). European Food Research Technology 233:1049-1055

62. Wang ZT, Geng YB, Liang T (2020) Optimization of reduced chemical fertilizer use in tea gardens based on the assessment of related environmental and economic benefits. Sci Total Environ 713:136439

63. Widdig M, Heintz-Buschart A, Schleuss PM, Guhr A, Borer ET, Seabloom EW, Spohn M (2020) Effects of nitrogen and phosphorus addition on microbial community composition and element cycling in a grassland soil. Soil Biol Biochem 151:12

64. Yan P, Shen C, Fan L, Li X, Zhang L, Zhang L, Han W (2018) Tea planting affects soil acidification and nitrogen and phosphorus distribution in soil. Agr Ecosyst Environ 254:20-25

65. Yang XD, Ma LF, Ji LF, Shi YZ, Yi XY, Yang QL, Ni K, Ruan JY (2019) Long-term nitrogen fertilization indirectly affects soil fungi community structure by changing soil and pruned litter in a subtropical tea (Camellia sinensis L.) plantation in China. Plant Soil 444:409-426

66. Yao F, Yang S, Wang ZR, Wang X, Ye J, Wang XG, DeBruyn JM, Feng X, Jiang Y, Li H (2017) Microbial taxa distribution is associated with ecological trophic cascades along an elevation gradient.

Frontiers in Microbiology 8, 2071

67. Zhang T, Chen HYH, Ruan H (2018) Global negative effects of nitrogen deposition on soil microbes. The ISME Journal 12:1817-1825

68. Zhang XM, Johnston ER, Liu W, Li LH, Han XG (2016) Environmental changes affect the assembly of soil bacterial community primarily by mediating stochastic processes. Glob Change Biol 22:198-207

69. Zheng Q, Hu YT, Zhang SS, Noll L, Bockle T, Dietrich M, Herbold CW, Eichorst SA, Woebken D, Richter A, Wanek W (2019) Soil multifunctionality is affected by the soil environment and by microbial Choo community composition and diversity. Soil Biol Biochem 136:107521

70. Zheng W, Zhao ZY, Lv FL, Wang RZ, Wang ZH, Zhao ZY, Li ZY, Zhai BN (2021) Assembly of abundant and rare bacterial and fungal sub-communities in different soil aggregate sizes in an apple orchard treated with cover crop and fertilizer. Soil Biol Biochem 156:13

71. Zhou JZ, Ning DL (2017) Stochastic community assembly: Does it matter in microbial ecology? Microbiol. Microbiology molecular biology reviews: MMBR 81:32

\section{Figures}




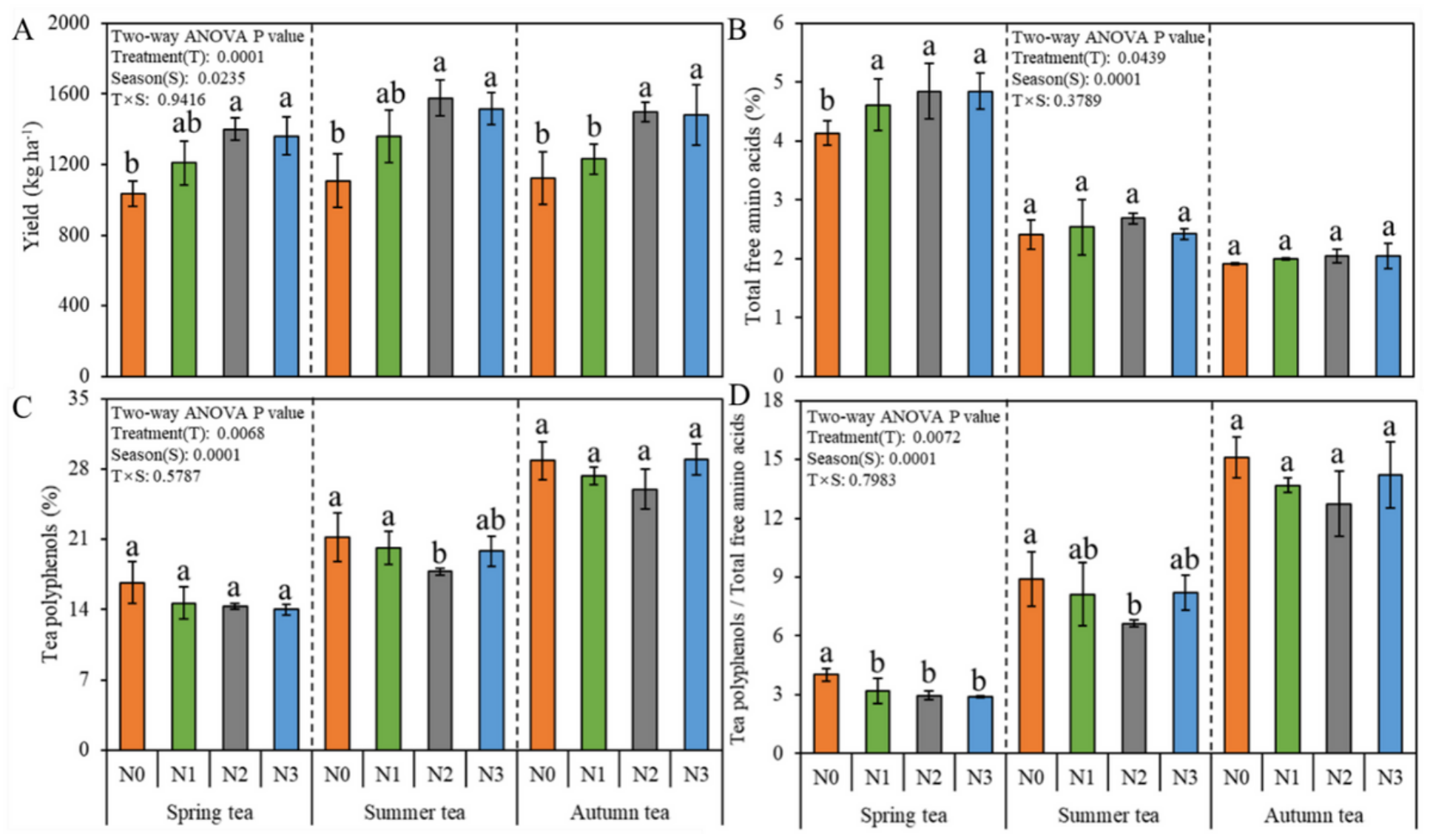

Figure 1

Tea yield and quality under different $\mathrm{N}$ fertiliser rates in spring, summer, and autumn. Standard deviations of three replicates are represented as error bars. Different letters above the bars indicate significant differences $(P<0.05)$ between $N$ fertiliser treatments in the same harvest season. N0, N1, N2, and N3 refer to $\mathrm{N}$ fertiliser application rates of $0,120,360$, and $600 \mathrm{~kg}$ ha- $1 \mathrm{y}-1$ for 5 years.
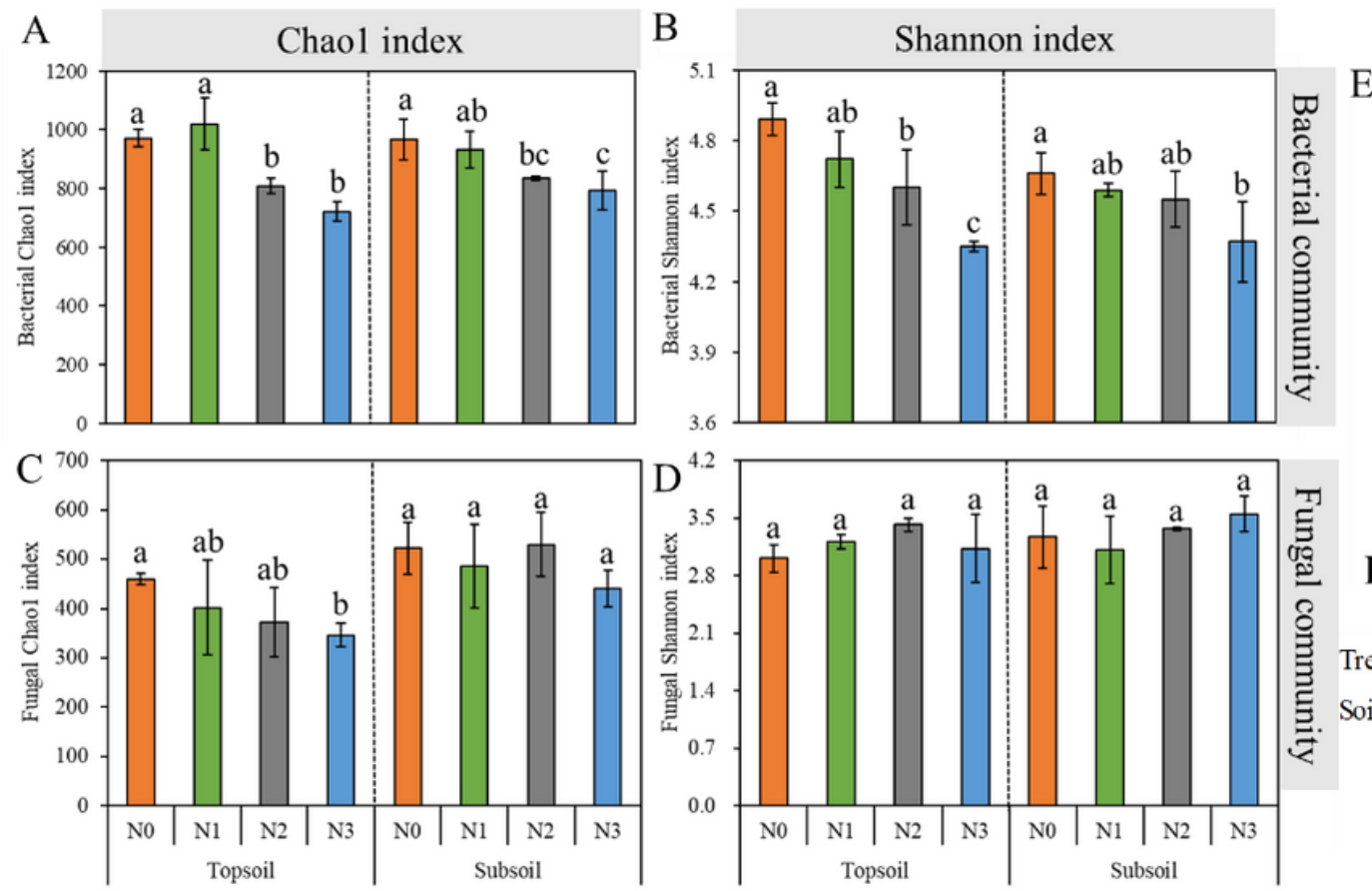

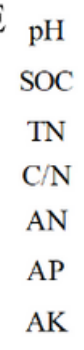

$\mathrm{NH}_{4}{ }^{+}$

$\mathrm{NO}_{3}{ }^{-}$

F

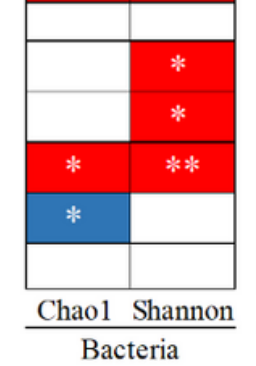

Bacteria
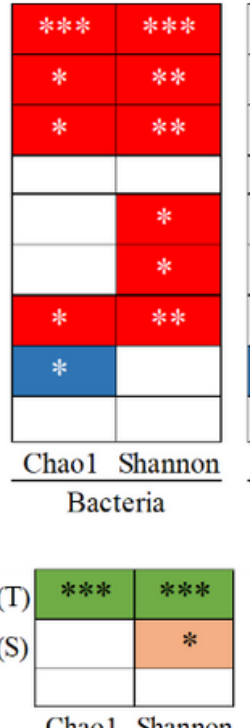

Chaol Shannon Bacteria

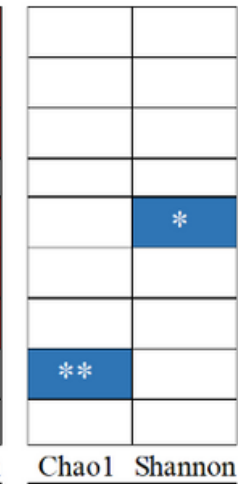

Fungi

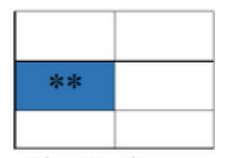

Chaol Shannon 
Chao1 and Shannon indices of (A, B) bacterial and (C, D) fungal communities under different $\mathrm{N}$ fertiliser application rates. Standard deviations of three replicates are represented as error bars. Different letters above the bars indicate significant differences $(P<0.05)$ between $N$ fertiliser treatments under the same soil layer (topsoil: $0-25 \mathrm{~cm}$, subsoil: $25-50 \mathrm{~cm}$ ). N0, N1, N2, and N3 refer to $\mathrm{N}$ fertiliser application rates of $0,120,360$, and $600 \mathrm{~kg}$ ha-1 $\mathrm{y}-1$, respectively, for 5 years. (E) Pearson's correlation between soil properties and alpha diversity of bacteria and fungi. Red and blue boxes indicate positive and negative correlations between alpha diversity index and soil properties. (F) Two-way ANOVA analysis results; *P < $0.05,{ }^{*} \mathrm{P}<0.01$, and $* * * P<0.001$. SOC: soil organic carbon; TN: total nitrogen; AN: alkali-hydrolysable N; AP: available phosphate; AK: available potassium.
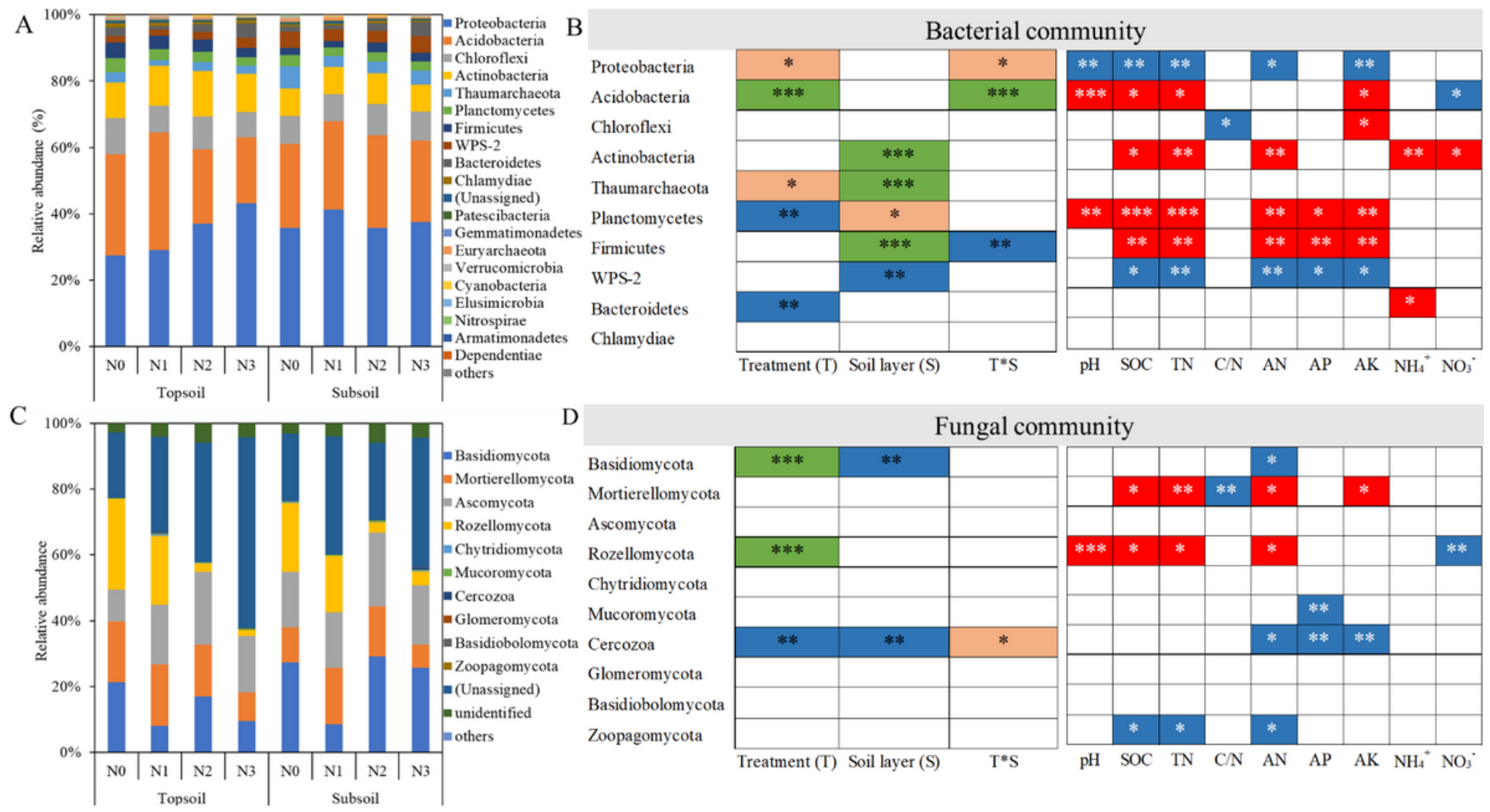

$\mathrm{D}$
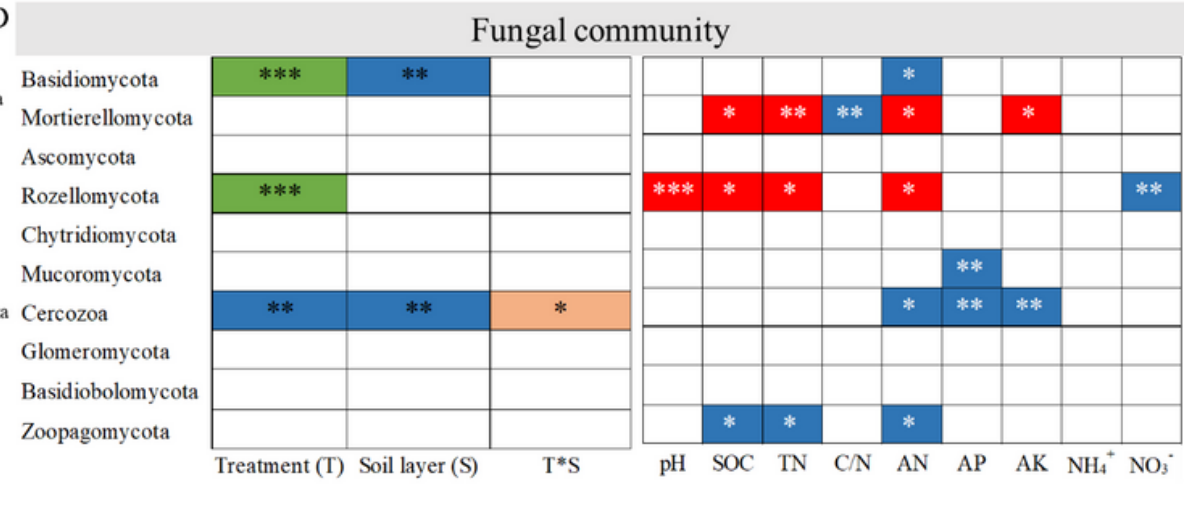

Figure 3

Major phyla of (A) bacterial and (C) fungal communities under different $\mathrm{N}$ fertiliser application rates and soil layers (topsoil: 0-25 cm, subsoil: $25-50 \mathrm{~cm}$ ). Results from two-way ANOVA and Pearson's correlation analysis between soil properties and relative abundance of top 10 (B) bacterial and (D) fungal phyla. *P < 0.05 , ${ }^{\star} \mathrm{P}<0.01$, and ${ }^{*} * \mathrm{P}<0.001$. Red and blue boxes indicate positive and negative correlations between the relative abundance of major phyla and soil properties, respectively. SOC: soil organic carbon; TN: total nitrogen; AN: alkali-hydrolysable N; AP: available phosphate; AK: available potassium. N0, N1, $\mathrm{N} 2$, and $\mathrm{N} 3$ refer to $\mathrm{N}$ fertiliser application rates of $0,120,360$, and $600 \mathrm{~kg}$ ha-1 $\mathrm{y}-1$, respectively, for 5 years. 

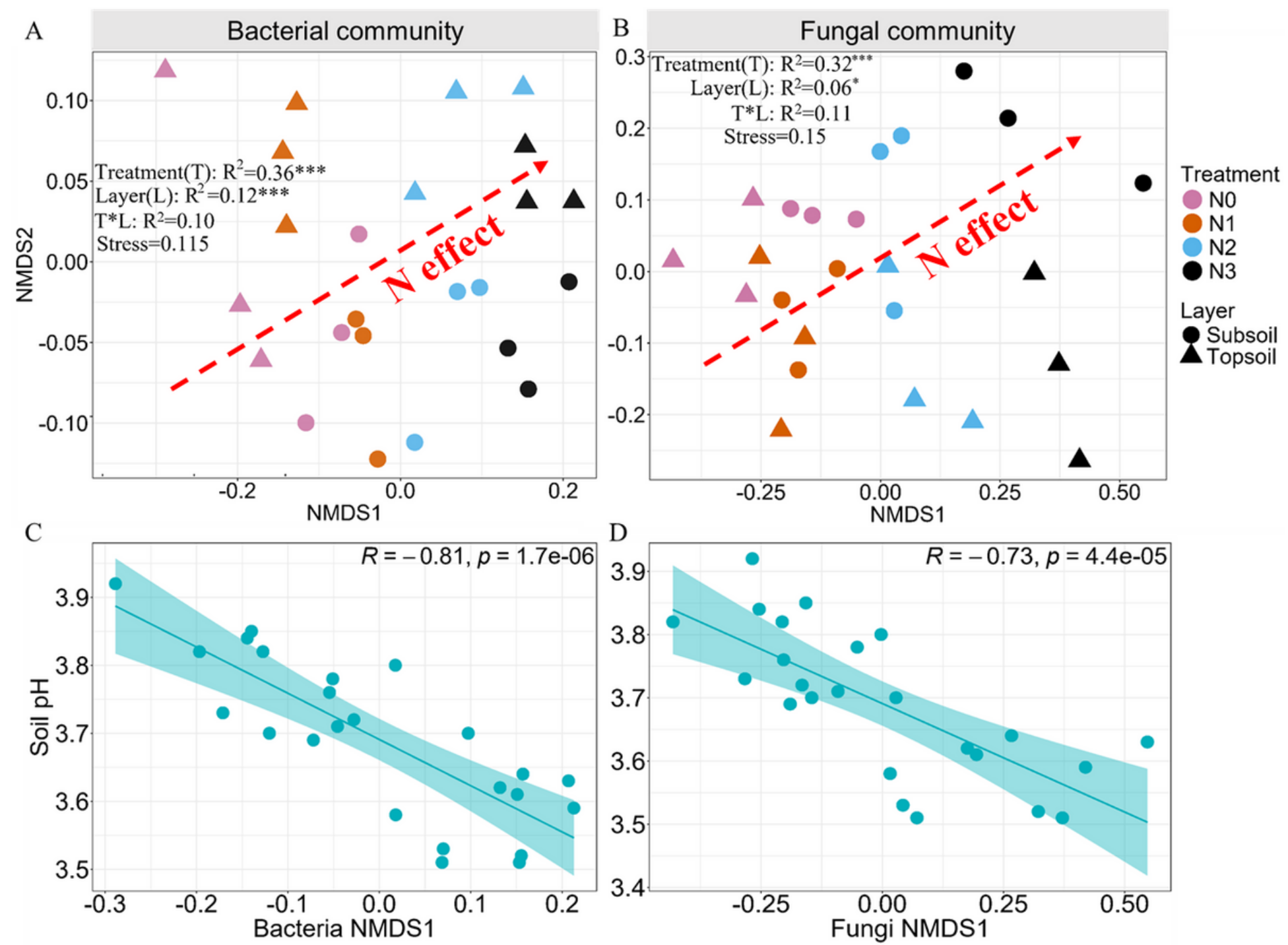

Figure 4

Non-metric multidimensional scaling (NMDS) based on the Bray-Curtis dissimilarities of (A) bacterial and (B) fungal communities in the topsoil $(0-25 \mathrm{~cm})$ and subsoil $(25-50 \mathrm{~cm})$ under different $\mathrm{N}$ application rates. N0, N1, N2, and N3 refer to N fertiliser application rates of $0,120,360$, and $600 \mathrm{~kg} \mathrm{ha}-1$ $y-1$, respectively, for 5 years. Linear regressions for (C) bacterial and (D) fungal NMDS1 values and soil $\mathrm{pH}$ values. Shaded areas represent $95 \%$ confidence intervals. 


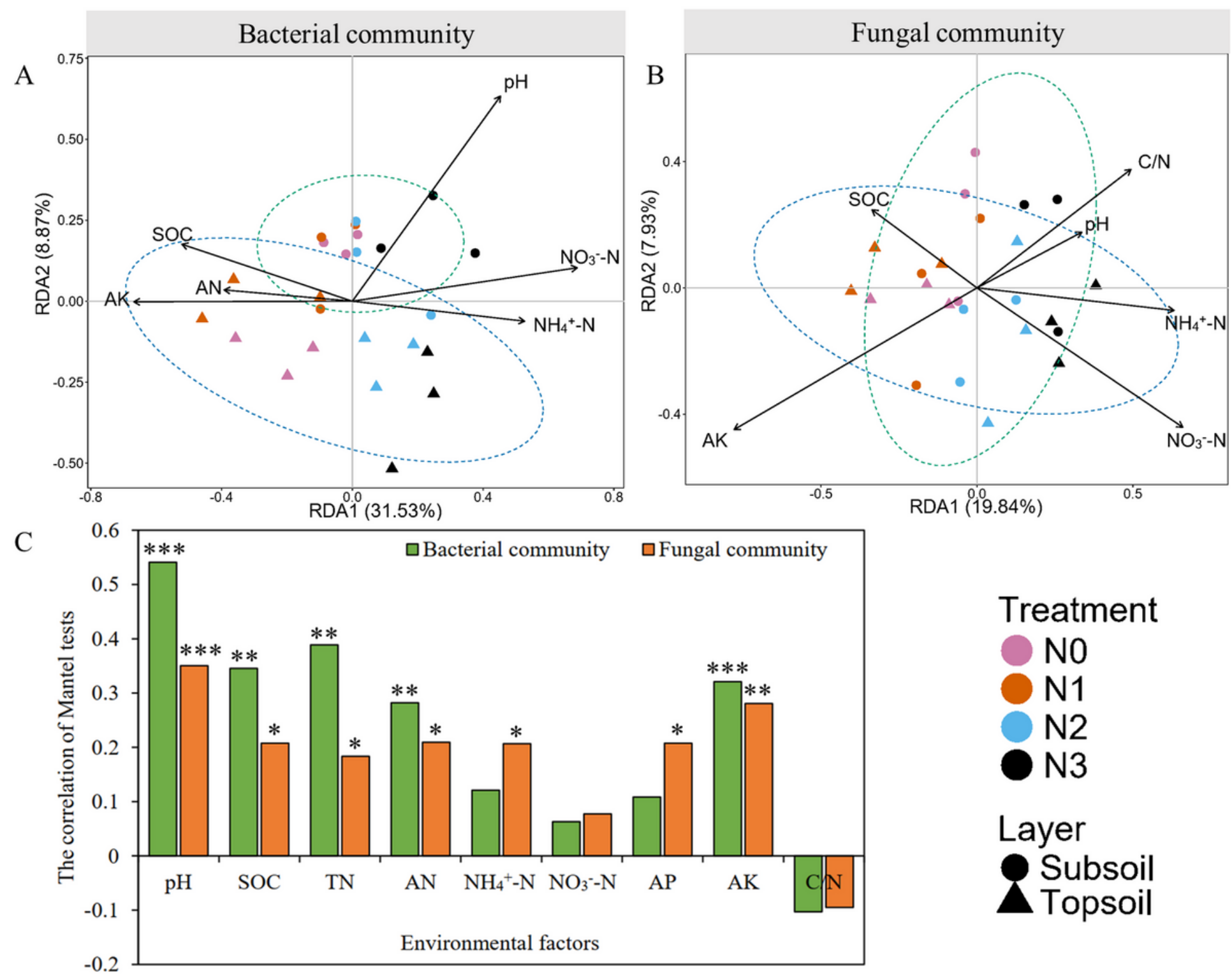

\section{Figure 5}

Canonical redundancy analysis (RDA) of (A) bacterial and (B) fungal communities with different $N$ fertiliser application rates and soil layers (topsoil: 0-25 cm, subsoil: 25-50 cm). N0, N1, N2, and N3 refer to $\mathrm{N}$ fertiliser application rates of $0,120,360$, and $600 \mathrm{~kg}$ ha-1 $\mathrm{y}-1$, respectively, for 5 years. (C) Mantel's analysis of the relationships between soil bacterial and fungal community structures and environmental variables. SOC: soil organic carbon; TN: total nitrogen; AN: alkali-hydrolysable N; AP: available phosphate; AK: available potassium. 


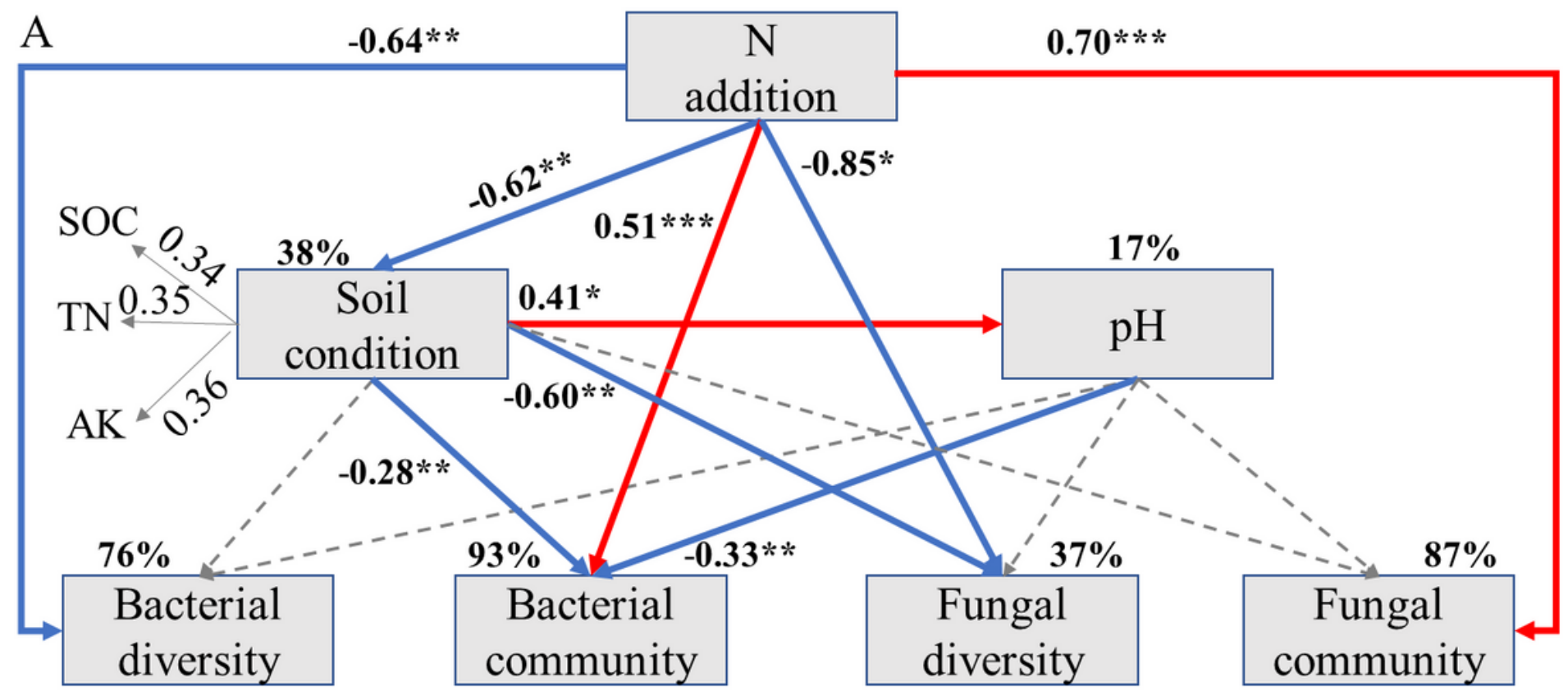

B

\section{Goodness of Fit $=\mathbf{0 . 7 2}$}
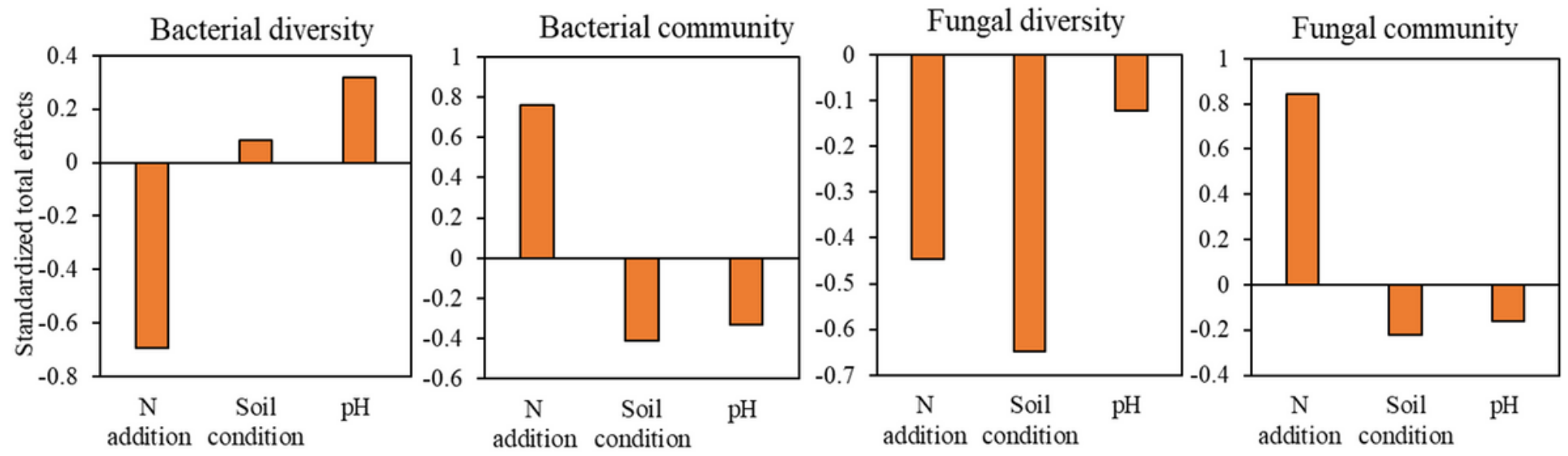

Figure 6

(A) Partial least squares path modelling (PLS-PM) analysis of direct and indirect influences of $\mathrm{N}$ fertiliser application on bacteria and fungi. Observed or latent variables are illustrated in the box. 1,000 bootstraps were conducted to estimate path coefficients. Positive and negative effects are presented by red and blue arrows, respectively. Path coefficients that were insignificantly different from zero are shown as dashed lines; ${ }^{*}<<0.05,{ }^{\star *} P<0.01$, and ${ }^{\star \star *} P<0.001$. Percentages above the boxes represent the explanatory degree of variables. The goodness-of-fit was used to assess the model. (B) Standardised total effects of $\mathrm{N}$ fertiliser application, soil condition, and soil pH on bacteria and fungi. SOC: soil organic carbon; TN: total nitrogen; AK: available potassium. 

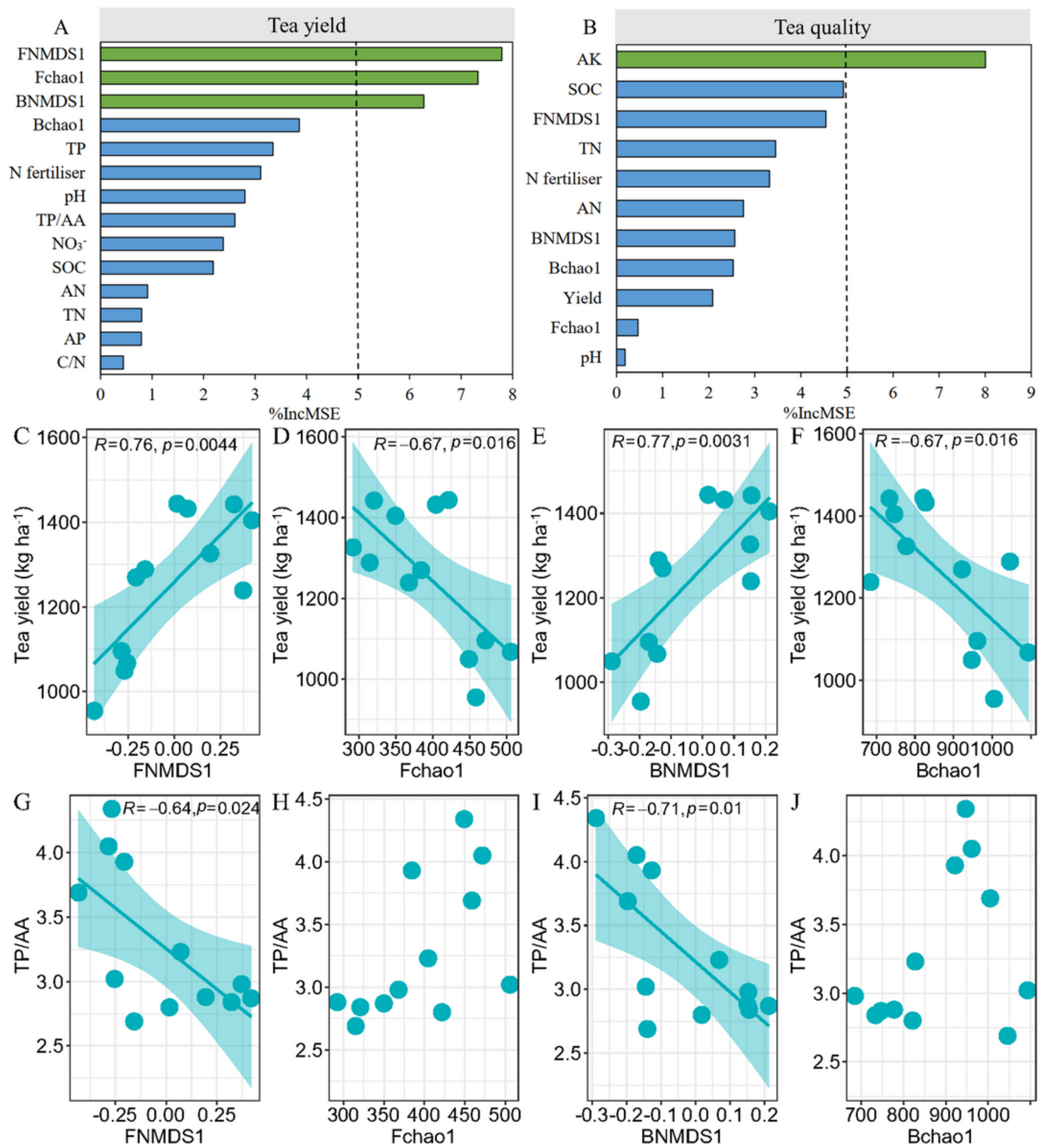

Figure 7

Random forest analysis for the determination of factors affecting tea (A) yield and (B) quality. Pearson's correlation analysis between microbiome and tea (C-J). BNMDS1, FNMDS1: Non-metric multidimensional scaling (NMDS) values based on the Bray-Curtis dissimilarities of bacterial and fungal communities, respectively; Bchao1 and Fchao1 are Chao1 indices of bacterial and fungal communities, respectively; SOC: soil organic carbon; TN: total nitrogen; AN: alkali-hydrolysable N; AP: available phosphate; AK: 
available potassium; TP: total polyphenols; TP/AA: ratio of tea polyphenol to total free amino acids; $\mathrm{N}$ fertiliser: $\mathrm{N}$ fertiliser application rate.

\section{Supplementary Files}

This is a list of supplementary files associated with this preprint. Click to download.

- Graphicalabstract.png

- Supplementaryinformation.docx 